\title{
A pedagógusok digitális átállásról, digitális oktatási stratégiáról és a digitális eszközök oktatási alkalmazásáról való gondolkodásának feltáró jellegü vizsgálata
}

\section{Bevezetés}

Az iskolaszámítógép program az 1980-as évek elején kezdődött: a programot ami a számítástechnika oktatás bevezetését, hosszú távú programjának kidolgozását és az ehhez szükséges technikai feltételek biztosítását tüzte ki célul - a Müvelődési Minisztérium 1981-ben indította el. A középiskolák és az általános iskolák az 1982/83-as tanévben kapták meg a központi keretből finanszírozott első, HT-1080Z típusú ,,school computer”-eket, és ezzel egyidejüleg föllángolt a vita pedagógus és nem pedagógus körökben arról, hogy van-e helye a számítógépeknek az iskolákban, illetve a tanítás-tanulás folyamatában.

A vita jó néhány évig tartott, majd okafogyottá vált, hiszen a számítógépek nemcsak megjelentek az iskolákban, de ott is maradtak, és megtalálták helyüket a pedagógiai folyamatokban (is). Előbb számítástechnika, majd informatika néven új stúdium jelent meg a tantárgyak között, amit a különböző, egymást elég sürün váltó kormányok hol magasabb, hol alacsonyabb óraszámokkal illettek a központi 
tantervekben. Az is viszonylag hamar kiderült, hogy a számítógépes környezetnek nemcsak az informatika órákon van helye, hanem szinte minden szaktárgyi foglalkozáson élni kívánnak a pedagógusok és a tanulók, hallgatók az informatika nyújtotta lehetőségekkel. Sőt; a „kakaóbiztos klaviatúrák” kapcsán néhány évvel ezelőtt kialakult politikai csatározás óta az is mindenki számára kiderült, hogy ezek az intelligens eszközök már a kisgyermekkori nevelés területein is jelen vannak-lesznek. Napjainkban ízlelgetjük az információs társadalom, információs és kommunikációs technológiák, digitális kompetenciák, digitális írástudás, digitális jólét, digitális szakadék, digitális átállás fogalmakat, és lassan - ha nem is fogadjuk el - tudomásul vesszük, hogy úton-útfélen okostelefonjukat birizgáló, gyakran fülhallgatóval a fülükben közlekedő fiatalokkal találkozunk.

A jelenség nem magyar sajátosság; szerte a világon ugyanezt tapasztalhatjuk. Mára az is világossá vált, hogy a probléma megkerülhetetlen. Magyarország kormánya a 2012/2015. (XII. 29.) Korm. számú határozatában megfogalmazta az internetről és a digitális fejlesztésekről szóló nemzeti konzultáció eredményei alapján végrehajtandó Digitális Jólét Programját, majd az 1536/2016. (XII. 29.) Korm. számú határozatával elfogadta Magyarország Digitális Oktatási Stratégiáját ${ }^{1}$.

Jelen vizsgálódás célja a pedagógusok előismereteinek és a továbbképzést befolyásoló sajátosságainak a feltáró megismerése a digitális pedagógiai kultúra fejlesztéséhez kapcsolódóan az alábbi témákban:

- a pedagógusoknak a digitális biztonság, adatvédelem területéhez kapcsolódó ismeretei,

- pedagógiai tapasztalatok, módszertani 'jó gyakorlatok', összefoglalóan a tudásmegosztás offline és online jellemzői,

- a digitális eszközök iskolai alkalmazásának helyzete.

Vegyük sorra a fenti témákat, és böngésszünk egy kicsit a világhálón az ezekkel kapcsolatos írások között - a teljesség igénye nélkül!

\section{Digitális biztonság, adatvédelem}

A digitális biztonságról hasznos ismereteket találunk Ollé János „Digitális felelősség, digitális etikett, digitális biztonság” című prezentációjában. A szerző a digitális biztonságot az alábbi részterületekre osztja:

\footnotetext{
${ }^{1}$ http://www.kormany.hu/download/0/cc/d0000/MDO.pdf
} 
- információbiztonság

- $\quad$ az eszközhasználat biztonsági kérdései

- $\quad$ tevékenységhez köthető biztonság

- online zaklatás, cyberbulling, identitáslopás

- felületes, a következmények tüneti kezelésére irányuló gondolkodás

- régimódi ,pedagógiai” válaszok online tevékenységre

- negatív tevékenység kiragadása a komplex viselkedésből

- reális tartalmi és tevékenységbeli alternatíva hiánya

- $\quad$ fizikai veszélyforrások

- $\quad$ informatikai bünözés

- humán kockázat

- megfigyelés

- $\quad$ illetéktelen és szemtelen adatgyüjtés

A digitaliscsalad.hu honlapon „Digitális biztonság: a szülőket is el kell érni” címü cikkében ${ }^{2}$ Tünde, a szerző, Matusek Zsuzsa internetbiztonsági oktatót kísérte el egy általános iskola nyolcadik osztályában tartott előadására. „Elsőre kicsit megdöbbentő volt, amilyen vehemenciával és nyíltsággal kezelte Zsuzsa a (sajnos sok helyen tabunak számító) témákat. Aztán néhány perc múlva rájöttem: sikerének titka pont ez. Hogy nem maszatol, nem körülír, hanem kimondja, amit ki kell, legyen szó akár pedofíliáról vagy a szexuális tartalmú üzenetekről. Ami különösen tetszett, hogy az oktató úgy figyelmeztet az internetezés veszélyeire, hogy az első sokkon és ijedségen túl azonnal megnyugvást és megoldást is talál a hallgató: az oktató konkrét, világos szabályokat ismertet, amelyek betartása kivitelezhető, és a legtöbb esetben kiküszöbölhetők ezekkel a digitális világ veszélyei” - írja a szerző. A cikkből kiderül, hogy „Matusek Zsuzsa gyermekjogi képviselö, a Nemzetközi Gyermekmentő Szolgálat Safer Internet Programjának oktatója”, és „a program keretében óvodás kortól kezdve középiskolás korig tartanak előadásokat (a korosztályok életkori sajátosságainak figyelembevételével), de 'szülői értekezleteket' is szerveznek, ahol a szülőkkel beszélgetnek a digitális világ biztonságossá tételéről.” Utóbbi fórumokra is nagy szükség van, mert - ahogy Matusek Zsuzsa fogalmazott - ,,a felnőttek, illetve a

\footnotetext{
${ }^{2}$ https://www.digitaliscsalad.hu/biztonsag/digitalis-biztonsag-szuloket-el-kell-erni/
} 
szülők sem mindig tudják, mire is kell figyelni, ez az oka annak, hogy a szülőket is el kell érnünk".

Ugyancsak Tünde a szerzője a „Ne dobd oda a gyereked a pedofiloknak” címü cikknek $^{3}$ is, amelyben Matusek Zsuzsával a fotófeltöltés veszélyeiről készített interjút.

A négygyermekes Nefi „Ezért ne posztolj képet a gyerekedről” címü írásában ${ }^{4}$ azt a kérdést járja körbe, hogy posztolhat-e egy szülő képet a gyermekéről.

„A videojátékok sok mindenben segíthetnek” a címe annak a cikknek ${ }^{5}$, amelynek szerzője Villányi Gergő. Egyet kell értenünk azzal a megállapításával, hogy „ha eszköznek tekintjük a videojátékokat, akkor egyszerü háztartási eszközök példája alapján néhány felismeréshez is eljuthatunk. Vegyük például a konyhakést, ami nagyon hasznos eszköz és rengeteg módon könnyíti meg az életünket. Az eszköz maga tehát nem gonosz és nem is jó, a hatását viszont már nevezhetjük pozitívnak vagy negatívnak. Itt azonban megannyi kontextust kell figyelembe vennünk: a felhasználás módja, időtartama, a szükséges képességek, az életkor, tudatosság a használattal kapcsolatban.” A szerző végső következtetése, hogy „,a kutatás szerint pozitív hatásai is vannak a videojátékoknak". A cikk része egy, a témához kapcsolódó magyar feliratos TED video is.

Bogi háromgyermekes családanya. „Tízéves gyerekem megkapta első mobiltelefonját" címü cikkében ${ }^{6}$ hasznos tanácsokat olvashatunk arról, milyen körültekintő ,intézkedésekre” van szükségünk, mielőtt saját mobiltelefonjával a hátizsákjában először iskolába engedjük gyermekünket.

A digitális biztonság témakör fontosságát jelzi, hogy a Digitális Jólét Program és az Informatikai, Távközlési és Elektronikai Vállalkozások Szövetsége közösen kezdeményezi egy IT-biztonsági szakmai fórum létrehozását?

Az adatvédelemmel kapcsolatban az Európai Parlament és az Európai Unió Tanácsa is szükségét látta az ezzel kapcsolatos korábbi állásfoglalását frissíteni: a természetes személyeknek a személyes adatok kezelése tekintetében történő védelméről és az ilyen adatok szabad áramlásáról, valamint a 95/46/EK rendelet

\footnotetext{
${ }^{3}$ https://www.digitaliscsalad.hu/biztonsag/ne-dobd-oda-gyereked-pedofiloknak/

${ }^{4}$ https://www.digitaliscsalad.hu/biztonsag/ezert-ne-posztolj-kepet-gyerekedrol/

5 https://www.digitaliscsalad.hu/elmeny/videojatekok-rosszak-nem-gondolnank-mennyimindenben-segithetnek-gyereknek/

${ }^{6}$ https://www.digitaliscsalad.hu/elmeny/tizeves-gyerekem-megkapta-elsookostelefonjat/

${ }^{7}$ https://hirlevel.egov.hu/2017/08/05/a-digitalis-jolet-program-es-az-ivsz-kozosenkezdemenyezi-egy-it-biztonsagi-szakmai-forum-lerehozasat/
} 
hatályon kívül helyezéséről szóló 2016/679 rendeletben foglaltakat ${ }^{8}$ 2018. május 25-töl kell alkalmazni ${ }^{9}$.

Január 28-án tartják az adatvédelmi világnapot, melynek célja, hogy felhívja a figyelmet az adatvédelem fontosságára. 2015-ben az adatvédelmi világnap alkalmából beszélgetett dr. Péterfalvi Attilával, a Nemzeti Adatvédelmi és Információszabadsági hatóság elnökével Szabados Balázs, a Magyar Nemzet újságírója. Az interjúból ${ }^{10}$ kiderül, hogy adatvédelmi szempontból gyermekeink vannak a legnehezebb helyzetben, és az egyik legnagyobb probléma a digitális adatvédelem kérdése: „Azok az új technológiai fejlesztések, melyek folyamatosan jelennek meg a piacon, azok is új adatvédelmi veszélyeket jelentenek. Kiemelném például a biometrikus azonosítást, valamint a drónokkal kapcsolatos aggályokat" - mondja Péterfalvi Attila. Majd így folytatja: „Szeretnénk az adatvédelmi tudatosságot elmélyíteni mind a magánszemélyek, mind a cégek esetében, amivel adott esetben saját magunkat védhetjük meg a visszaélésekkel szemben. A digitális világban a jogi védelem mellett kiemelkedően fontos az adatbiztonság is. Itt nagyon sok mindent tehet a felhasználó az egyes adatvédelmi beállításokkal. Gyerekek esetén például nagyon fontos mind a szülők, mind az iskolák részéről, hogy a csemeték korának megfelelő szürőkkel lássák el a böngészőket, hogy csakis olyan tartalmakat láthassanak, amik nekik valóak. Manapság sajnos rengeteg adatot megosztunk magunkról, főleg amióta elterjedtek a közösségi oldalak. Tisztában vagyunk-e azzal, hogy mindenki a saját adatával rendelkezik, nem pedig máséval? Tudjuk-e azt, hogy ha posztolunk egy fotót, amin mások is szerepelnek, annak jogaival azok a személyek is rendelkeznek?” Arra a kérdésére, hogy milyen szinten áll adatbiztonság szempontjából a mai magyar átlagfelhasználó, a következő választ kapta az újságíró: „Erre nézve nincsenek egzakt adataink, de azt gondolom, hogy nem túl jó a helyzet. Azokban az országokban, ahol régebb óta használják az internetet, jobban kialakult ennek a kultúrája, ott valamivel tudatosabbak a felhasználók. És azt sem mondanám, hogy ez életkorfüggő. Nem vagyok meggyőződve, hogy a fiatalok az adatvédelmi beállításokat jobban használják, mint az idősebbek, pedig tulajdonképpen már ebbe a digitális világba születtek bele. Ezért gondolom, hogy az adatbiztonságra, az internet tudatos használatára nagy hangsúlyt kell fektetni, és ezért hasznos például az adatvédelem világnapja vagy a biztonságos internet napja ${ }^{11}$ is, melyek felhívhatják az emberek figyelmét ezekre a dolgokra." Pedagógiai szempontból is

\footnotetext{
${ }^{8} \mathrm{https} / / /$ naih.hu/files/CELEX_32016R0679_HU_TXT.pdf

${ }^{9} \mathrm{https} / / /$ naih.hu/files/CELEX_32016R0679_HU_TXT.pdf

${ }^{10} \mathrm{https} / / / \mathrm{mno}$.hu/fogyasztovedelem/adatvedelem-es-internet-tanitani-kene-agyerekeknek-1269935

${ }^{11}$ Az Európai Unió kezdeményezésére február második hetének második napja a „Biztonságosabb Internet Napja”.
} 
érdekes Péterfalvi Attila véleménye azzal kapcsolatban, hogy hány éves kortól lenne szabad egy gyermeket internetközelbe engedni: „A mai világ teljesen felgyorsult, sok esetben már óvodásoknál láthatunk táblagépeket, okostelefonokat, tehát én nem mondanék alsó korhatárt az internettel kapcsolatban. A technikai fejlődés elől nem elzárkózni kell, hanem meg kell tanulni azt úgy használni, hogy magunknak ne okozzunk vele kárt. Azonban nagyon fontos, hogy a szülők felkészítsék a gyereküket a kockázatokra, és hogy telepítsék a szükséges szürőprogramokat. A hatóságunk most részt vesz egy európai projektben, melynek az lesz a célja, hogy egy adatvédelmi tananyagot alakítsunk ki, amit aztán az iskolákban akár informatikaórán, akár etika- vagy osztályfönöki óra keretében tanítanának a gyerekeknek. Ebben nemcsak a technikai beállításokról vagy jogi szabályozásról lenne szó, hanem arról is, hogy kihez fordulhatnak, amennyiben valamiféle problémát vagy visszaélést tapasztalnak."

Hunyor Erna Szofia „Digitális iskolakezdés: lényeg a biztonság” címü írásából ${ }^{12}$ megtudhatjuk, hogy ,a laptop, asztali gép, tablet, wifi router megvásárlása (...) nem csak anyagi terhet, de veszélyforrást, az egyre több iskolában bevezetett Elektronikus Osztálynapló pedig információvédelmi kihívásokat is jelent a családok számára".

Az adatbiztonsággal, adatvédelemmel kapcsolatos fogalmaknak, illetve az ehhez kapcsolódó jogszabályi háttérnek remek összefoglalását találjuk Tömösközi Péter „Adatbiztonság, adatvédelem" címü prezentációjában ${ }^{13}$. Erdősi Péter Máté „ECDL/ICDL IT Biztonság” címü, közel százoldalas jegyzete ${ }^{14}$, illetve Horváth Gergely Krisztián „Közérthetően (nem csak) az IT biztonságról” címet viselő, az előzőnél is terjedelmesebb könyve ${ }^{15}$ szintén hasznos olvasmány lehet minden, a téma iránt érdeklődő olvasó számára.

Kitűnő útmutatást ad a gyerekeknek szóló digitális tartalmak, szolgáltatások és alkalmazások létrehozásához a betterinternetforkids.eu internetes oldalon található kritériumrendszer ${ }^{16}$. Ebben a cikkben is nagy hangsúlyt kap az a megállapítás, hogy a gyermekek biztonsága, illetve személyes adataik védelme elsőrendü fontosságú!

\footnotetext{
${ }^{12} \mathrm{http} / / /$ profit7.hu/magazin-1/digitalis-iskolakezdes-lenyeg-a-biztonsag

${ }^{13} \mathrm{http} / / /$ slideplayer.hu/slide/2946935/

${ }^{14} \mathrm{https}: / /$ summers.hu/ecdl/s6/jegyzetek/it.pdf

${ }^{15} \mathrm{http} / / /$ www.kifu.gov.hu/kifu/sites/default/files/IT brosura_v7.pdf

${ }_{16} \mathrm{https} / / / \mathrm{www} \cdot$ betterinternetforkids.eu/documents/2067076/2162084/Checklist_Positive Content_provider_producer_HU.pdf/c9418535-8f6e-4d63-ab45-5e232515b251
} 
A digitális biztonság, illetve az adatvédelem kérdését néhány más országokban is kiemelten kezelik. Nézzünk erre néhány példát.

Natasha Singer „A diákoknak készült digitális oktatótermékek biztonsági hibáinak felfedése" címü, a New York Timesban megjelent cikkében ${ }^{17}$ (USA, 2015) elmesél egy történetet. Egy apa két fia a Raz-Kids.com-on kapott értőolvasási házi feladatot. Az oldal használatához regisztráció szükséges. Az apa, Mr Porterfield, aki egyébként szoftverfejlesztő, észrevette, hogy az oldal nemcsak kódolatlan volt, hanem a jelszavakat sem rejtjelezett szövegként tárolta. Így volt ez a legtöbb oktató-weboldallal, de a fő problémát az jelentette, hogy nem létezett egyértelmű definíciója annak, hogy mit jelent a 'biztonság' egy oktatási weboldal vagy alkalmazás számára. Mr Porterfield további 20 digitális terméket vizsgált meg, és egyéb biztonsági problémákat is talált. Értesítette a készítőket, akik közül néhányan komolyan vették az ügyet és javítottak (Pl Pearson, ClassDojo), a többiek viszont nem. A szakemberek arra hívták fel a figyelmet, hogy a nem biztonságos oldalak szinte felkínálják a felhasználókat (akik legtöbbje 13 év alatti) a hekkereknek, a társak általi adatlopásnak és zaklatásnak (cyberbullying). Hogy biztosítsák a felhasználókat a személyes adatok biztonsága felől, több mint 100 cég írta alá az önkéntes egyezményt egy átfogó biztonsági program használatára. Ez viszont nem kötelezi a többi oktatási oldalt biztonságos adatvédelmi rendszerek használatára...

Meghan Bogardus Cortez „4 tipp az iskolák számára a megfelelő privát szférával és biztonsággal kapcsolatban" címü írásában ${ }^{18}$ (USA, 2016) a következő szempontokat javasolja betartani az iskoláknak:

1. Amikor az iskola egy új digitális eszközt vásárol, az első dolog megnézni, hogy az eladó aláírta-e az előző cikkben említett adatvédelmi egyezményt. Fel kellene tenni továbbá a következő kérdéseket: Milyen adatokat tárolnak? Hol és miért tárolják azokat? Az adminisztrátoroknak, ismerniük kellene a szabályzatok alapjait:

a. FERPA (Az iskolának írásos szülői beleegyezést kell bekérni ahhoz, hogy a diákok adatait kiadják. Kivétel a helyi hivatalok, akkreditált szervezetek, Oktatási Minisztérium, de a szülőnek ekkor is értesülnie kell a gyermekeik adatainak kiadásáról.)

\footnotetext{
${ }^{17}$ https://www.nytimes.com/2015/02/09/technology/uncovering-security-flaws-indigital-education-products-for-schoolchildren.html

${ }_{18}$ https://edtechmagazine.com/k12/article/2016/10/4-tips-help-schools-privacy-andsecurity-compliance
} 
b. COPPA (Azt szabja meg, hogy a mobil alkalmazások, online játékok milyen adatokat kérhetnek a 13 éven aluli gyerekektől.)

2. Tanulni kell más iskoláktól, szakemberektöl. A Common Sense Education cég (Józan Ész Tanítás) összeállt 70 iskolával és körzettel, hogy elindítsák az Edtech Privacy Értékelő Platformot, hogy segítsék az adminisztrátorokat más oktatókat a megbízható szoftverek kiválasztásában. Ez egy átfogó, központosított, ingyenes forrás.

3. Fontos megismerni, hogyan kell reagálni egy szabályszegésre. Az iskolának ki kell dolgoznia egy tervet, amit gyakorolni is kell.

4. Tanítsuk meg a tanárokat és diákokat, hogyan válhatnak jobb digitális állampolgárokká. A lényeg, hogy ne csak az iskolában legyenek védve, hanem az élet minden területén.

Tara García Mathewson „Ki tartja biztonságban a diákok adatait a digitális tanulás korában?" címü cikkéből ${ }^{19}$ (USA, 2017) megtudjuk, hogy Baltimore megye a legkiemelkedőbb a diákok adatainak védelme és biztonsága szempontjából. A 13 körzet egyike, akik elnyerték a "Megbízható Tanulási Környezet" címet a CoSN ${ }^{20}$ töl. A címet 2016-ban ítélték oda először annak érdekében, hogy megmutassák, mit kellene a körzeteknek tenniük a megfelelö adatbiztonság eléréséhez. Hogy egy körzet jelentkezzen, a következö öt alapterületen kell bizonyítaniuk: vezetés, üzlet, adatbiztonság, osztály- és szakmai fejlődés.

Írországban létrehoztak és müködtetnek egy „Adatvédelem az iskolákban” címü honlapot. Az iskoláknak tudniuk kell a rájuk háruló személyes adatgyüjtéssel és feldolgozással kapcsolatos jogi kötelezettségeikröl, ebben áll ez a weboldal a segítségükre. Példákat hoz, hasznos linkeket, fő elveket ismertet, igazi útmutatást ad az iskoláknak az adatgyüjtés teljes folyamatára. A honlapról megtudhatjuk, hogy Írországban adatvédelmi rendeleteket adtak ki 1998-ban és 2003-ban az egyének személyes adatainak védelmére. 2003-ban az adatvédelmi biztos által kiadott „Útmutatás adatellenőröknek” címü ajánlást szétküldték az iskoláknak. A biometrikus adatok védelmére vonatkozóan is kiadtak egy javaslatot az oktatási intézmények számára.

Jenna Aston „Hogyan befolyásolja az adatvédelmi törvény az iskolák müködését” című cikkéből (Egyesült Királyság, 2016) megtudjuk, hogy az 1998-ban

\footnotetext{
${ }^{19} \mathrm{http}$ ///hechingerreport.org/keeping-student-data-safe-era-digital-learning/

${ }^{20} \mathrm{CoSN}$ : Konzorcium az iskolai hálózatokért
} 
elfogadott adatvédelmi rendelet értelmében mindenkinek, aki személyes adatokat tárol, be kell tartania az alábbi nyolc fó elvet:

1. igazságos, jogszerü használat

2. limitált ideig, specifikusan megfogalmazott célra

3. megfelelő, releváns módon, nem túlzóan

4. pontosan

5. nem hosszabb ideig, mint ami feltétlenül szükséges

6. az egyének adatvédelmi jogainak megfelelően

7. biztonsággal és biztonságban tartani

8. megfelelő felügyelet nélkül nem adható ki az Egyesült Királyságból. (Az ír szabályozásnál ez úgy módosul, hogy kérésre másolatot kell adni az adott személynek az adatairól.)

Azokra az iskolákra, amelyek nem tartják be a szabályzatokat, 500.000 fontnyi bírságot szab-hatnak ki, és az Ofstead minősítésük is romlik. Az összes oktatási intézménynek rendelkeznie kell a fentebb említett elveknek megfelelően elkészített szabályzatokkal:

- e-biztonság

- $\quad$ adatbiztonság

- elfogadható használat

- $\quad$ BYOD (Bring Your Own Device - azokra az oktatókra vonatkozik, akik saját eszközeiket (okostelefon, laptop, tablet) viszik be a munkahelyre és azokkal kapcsolódnak a szervezeti hálózatra.)

Ha ezek a szabályzatok megvannak, akkor a dolgozók is tudni fogják, mit kell tenniük, hogyan kell használniuk a technológiákat az iskolán kívül és belül, és azzal is tisztában lesznek, mi történik, ha nem tartják be a szabályokat. Ezeknek a leírásoknak a dolgozók mellett a szülők és diákok részére is elérhetőnek kell lenniük. Folyamatos tréningre van szükség, így ha változás következik be, a dolgozók is tudni fogják. A használt technológiáknak, webes-felületeknek biztonságosnak kell lenniük (tüzfal, kódolás, biztonságos szerverek). Arra is nagy gondot kell fordítani, hogy mi történik a leselejtezett készülékekkel. 


\section{A tudásmegosztás offline és online jellemzői}

Az 1990-es évek közepe táján „Informatika a közoktatásban” címmel évi rendszerességgel országos szakmai konferenciasorozatot szerveztünk. Az első ilyen rendezvényen Vámos Tibor akadémikus, a hazai számítógépes hálózatfejlesztés meghatározó személyisége a következőképpen fogalmazta meg a számítástechnika-informatika tanárok legfontosabb feladatát: „El kell érnünk, hogy a számítógépes környezet a felnövekvő nemzedék számára teljesen természetes közeg legyen..." Azóta alig húsz év telt el, s bármerre nézünk otthon, utcán, iskolában, munkahelyen, közintézményekben -, meg kell állapítanunk, hogy a Vámos Tibor által (is) jelzett irányban nagyon sokat haladtunk előre. Néha úgy érezzük, talán túlságosan is messzire jutottunk; nagy lépéseket tettünk, de időnként az út fontos részleteit átugrottuk. Szinte minden fiatal boszorkányos gyorsasággal tud SMS-t írni az okostelefonján, de nem biztos, hogy nagy részük tudna ihletetten fogalmazást írni szövegszerkesztővel az irodalomórán. Ügyesen megkeresnek bármilyen menő zeneszámot a Youtube-on, de elbizonytalanodnak, ha egy megadott témában kell az interneten talált források alapján rövid prezentációt készíteni. Itt van - vagy lenne - óriási felelőssége a pedagógusoknak; meg kell tanítani a gyerekeket az információs és kommunikációs technológiák értelmes használatára. Természetesen ezt megelőzően a pedagógusoknak kell megszerezniük az ehhez szükséges, napjainkban sokszor emlegetett digitális kompetenciákat.

Nézzünk meg néhány, a digitális átállással kapcsolatos pedagógiai tapasztalatokat, módszertani 'jó gyakorlatokat' ismertető cikket, jegyzetet az interneten, amelyekből az érdeklődő pedagógusok megismerhetik a tudásmegosztás offline és online jellemzőit!

Koltói Lilla, a Kecskeméti Főiskola Tanítóképző Főiskolai Karának (ma Neumann János Egyetem Pedagógusképző Kara) oktatója „Tudásmegosztás és teremtés tanárok online szakmai közösségében" címü, 2009-ben megjelent cikkében $^{21}$ a következőket olvashatjuk: „Az IKT eszközök, ezen belül a Web 2.0 eszközök megjelenése az oktatásban új kihívások elé állította a pedagógusokat. A technológia új tudásátadási módszereket hív életre, a tanárok szerepe sok tekintetben módosul: nem ők az információ, a tudás egyedüli birtokosai, feladatuk egyre inkább az információkeresési, tudásmegosztási stratégiák elsajátításának elősegítése. A tanítás sikerességében ezért fontos tényező a tanárok az IKT, valamint a Web 2.0 eszközökkel kapcsolatos attitüdje. A Web 2.0 eszközök nem csak a tanítási folyamatokban játszanak szerepet, hanem lehetőséget ad a pedagógusoknak formális és informális online szakmai közösségek alakítására.

\footnotetext{
${ }^{21}$ http://www.iskolakultura.hu/iol/iol_2009 42-51.pdf
} 
Ezek a szakmai közösségek fórumot teremthetnek a szakmai párbeszédnek, elősegíthetik a tudásmegosztást és új tudás létrehozását."

Gönczöl Enikő az Osztályfőnökök Országos Szakmai Egyesületének honlapján, az osztalyfonok.hu weboldalon megjelent, „A tudásmegosztás formális és informális közösségei” címü írásában ${ }^{22}$ azt a kérdést feszegeti, „vajon milyen mélyebb okai lehetnek annak, hogy bár évről évre igen sok jó kísérlet, program, központi és helyi innováció indul el a közoktatásban, ezek döntő hányada rövid életü. A támogató anyagi forrás elapadását követően a fejlesztések többsége abban az intézményben is elhal, amelyikben megvalósult. Más intézményre pedig szinte soha sem terjed át követhető jó gyakorlatként..."

Kárpáti Andrea, Szálas Tímea és Kuttner Ádám „Közösségi média az oktatásban - Facebook-esettanulmányok" címü tanulmányuk ${ }^{23}$ bevezetőjében a következőképpen foglalják össze kutatásuk lényegét: „A közösségi oldalak, elsősorban a Facebook térhódítása felveti a kérdést, vajon lehetne-e kapcsolatteremtés és programok meghirdetése mellett oktatási célra is felhasználni az oldalakat, melyeken tanítványaink naponta órákat töltenek. A virtuális kapcsolatteremtő színterekkel támogatott tanulás vizsgálatával foglalkozó empirikus kutatások száma még mindig alacsony, de a nemzetközi szakirodalom jelentős része alátámasztja a közösségi oldal és a blogok oktatási lehetőségeit. Ez a tanulmány áttekinti ezeket a kutatásokat, majd két iskolai kísérlet bemutatásával igazolja: a Web 2.0 eszközök átalakítják mindennapjainkat és a tanulás új színtereit jelentik."

Az osztalyfonok.hu weboldalon „Ez történt a 2. Digitális pedagógus konferencián” összefoglaló címmel kitünő válogatást találunk ${ }^{24}$ az IKT eszközök használatával kapcsolatos módszertani 'jó gyakorlatokból':

- Tarné Éder Marianna szerint „elhibázott lépés lenne, ha a digitális technológiákat, az IKT eszközök alkalmazását hirtelen kötelezővé tennénk, és azt hangsúlyoznánk, hogy csak 'így', csak ezekkel az eszközökkel történhet színvonalas oktatás".

- $\quad$ Nagy Ildikó Mária úgy véli, ,az óvodások könnyen ráéreznek a technikai alkalmazások kezelésére, az interaktív tábla müködtetésére, ezért az óvodai nevelésben használt számítógépes programokat és online játékokat kiemelt gondossággal kell kiválasztani”. Megítélése szerint ,a gyermekek találkozása a számítógéppel és az interaktív tábla játékos

\footnotetext{
${ }^{22}$ http://www.osztalyfonok.hu/cikk.php?id=677

${ }^{23} \mathrm{http} / / /$ epa.oszk.hu/00000/00011/00169/pdf/EPA00011_Iskolakultura_2012-10_011042.pdf

${ }^{24}$ http://www.osztalyfonok.hu/cikk.php?id=1240
} 
alkalmazása változatossá teszi az óvodai életet, új felfedező utakat járnak be és nem utolsó sorban emberséges és gyermekbarát hatásával is megismerkedhetnek". Fontosnak tartja, hogy az óvodások otthonról hozott digitális tapasztalataira is kellő hangsúlyt fektessenek az óvodai tevékenységek során.

- Dr. Ujhelyiné Szeverényi Irma arra figyelmeztet, hogy bár „a digitális kor gyermekeinek sajátosságai sok tekintetben eltérnek az elmúlt társadalmak nemzedékeihez képest, egy azonban minden kor minden gyermekére jellemző, mégpedig az, hogy szeretetre vágyik, és gyermekségénél fogva életeleme a játék. Ezek olyan elemi ösztönök, szükségletek, amelyek kielégítése legalább olyan fontos a gyermeki fejlödés során, mint a fizikai növekedéshez elengedhetetlen táplálék".

- Benedekné Fekete Hajnalka kisiskolások számára online IKT tanulókört indított, s ezt a következőkkel indokolja: „Az online IKT tanulókör indításával arra próbálok utat keresni, hogy tartalomalakító, tartalomlétrehozó digitális alkalmazások megismertetésével olyan képességeket fejlesszek, amelyek nem gyömöszölhetők tantárgyi keretek közé. A Tanulókör indításakor fontosnak éreztem, hogy olyan gyerekeket is bevonjak, akik a szociális státuszuk alapján hátrányos helyzetűek, vagy beilleszkedési-tanulási problémával küzdenek. Ezt az akadályt megugrottuk..."

- Kis Anitától, illetve Vindics Péternétől megtudhatjuk, hogy digitális tábla nélkül is van IKT-s élet, mert a digitális tananyagok interaktív tábla nélkül is megtaníthatók.

- Mirkné Haba Anikó bevallja, hogy édesanyaként és tanárként nem szerette a számítógépes játékokat; féltékeny és irigy volt rájuk. Ugyanakkor egyre jobban izgatta, ,mit tudnak ezek a programok, mi a titkuk, amivel elvarázsolnak kicsit és nagyot”. A kíváncsisága tettekre sarkallta: „A számítógépes játékok népszerűségét az általuk kiváltott flow-élmény okozza. Alkalmazhatnánk-e ugyanazokat a pszichológiai elveket és technikai trükköket az iskolai tananyaghoz kapcsolódó tanulás támogatására? Erre a kérdésre született próbálkozás a Versike oktatóprogram, amelynek lényege a tanulók játékos verstanítása fokozatosan növekvő kognitív erőfeszítés útján, több modalitás használatával és az önellenőrzés lehetőségével. A szoftver hatástanulmányát jelentő kutatásban (...) kimutattam a Versike oktatóprogram által előidézett fokozott flow élményt. Teljesítmény szempontjából is szignifikánsan jobb eredmények születtek használata során..." 
Simon Gabriella „Az iskolai tudás és az internet” című tanulmánya ${ }^{25}$ „,az iskolai tudás és az Internet kapcsolatának történeti keretbe ágyazásával az iskolában elsajátítható tudás egy lehetséges értelmezésén keresztül tekinti át e tudás adaptivitása és az Internet használata közötti lehetséges összefüggést. Egyrészt rá kíván világítani arra, hogy az Internet elérhetőségének területén hazánkban egyenlőtlen hozzáférést mutató megosztottság tapasztalható, mely növeli a világháló iskolai alkalmazásának jelentőségét, másrészt - ezzel összhangban amellett érvel, hogy az iskolai Internet-használat jól kiaknázható lehetőség a tudás PISA tesztekben mérhető adaptivitásának megteremtésében, hiszen a fiatalok világháló iránti érdeklődése a kezdetektől folyamatosan kimutatható.”

Bodnár Zsuzsa „Tudásmegosztás - kivel, mikor, hogyan?” című írásának ${ }^{26}$ bevezetőjében azt a kérdést veti föl, hogy vajon mennyire ismertek és elterjedtek a hazai gyakorlatban a tudásmegosztás tervezett formái. A cikkben több ismert szakember véleményéből szemezget. A tanulmányból megtudhatjuk többek között, hogy ,a tudás szervezeten belüli áramlásának három legfőbb akadálya a pozícióféltés, az érdektelenség és a bizalom hiánya”, továbbá azt is, hogy „,intenzív és értékes tudásmegosztás csak olyan emberek között jön létre, akik bíznak egymásban. A ma uralkodó, társadalmi szintű bizalomhiány nem kedvez az ilyenfajta szemléletváltásnak". Az egyik legfontosabb megállapítása a szerzőnek, hogy ,a felnövekvő nemzedék számára csak akkor lehet a versengés helyett a tudás megosztásának gondolatát vonzóvá tenni, ha már az iskolában megismerkedhetnek ennek előnyeivel..."

A Pécsi Tudományegyetem munkatársainak több éve tartó kutatásairól ad rövid összefoglalót Rumpf Nikoletta „Hogyan használja a médiát a Z-generáció?” címü cikkében $^{27}$. Általában az 1980 és 1999 között születetteket soroljuk ide. „A kutatók szerint ugyan attitüdalapú részekre bonthatjuk a generációt, de vannak univerzális jellemzők is: náluk értékké a tapasztalat vált, nem a tudás. Ez látható, magatartásuk alapja: mindenhol ott kell lenni, mindent látni és természetesen dokumentálni kell, majd megosztani. Kiderült, hogy a túl sok lehetőség miatt az általános gyorsaság már nem elég, egyszerre kreatívnak is kell lenni; a technológia és fesztiválfüggőség mellett kell idő az alibi-hobbikra, melyekkel ügyesen lehet kerülni a munkát vagy a családot..."

A moderniskola.hu honlapon megjelent „Az online világban is fontos a kézírás hogyan használjuk az Okosportált?” címü interjú ${ }^{28}$ alanyától, Kalászné Tímár

\footnotetext{
${ }^{25} \mathrm{http}: / /$ www.kre.hu/ebook/dmdocuments/oktatasi_segedanyag/chap_16.html

${ }^{26} \mathrm{http}: / /$ recity.hu/tudasmegosztas-kivel-mikor-hogyan/

${ }^{27} \mathrm{http}: / /$ media20.blog.hu/2014/11/22/hogyan hasznalja_a mediat_a z-generacio

${ }^{28} \mathrm{http}$ ://moderniskola.hu/2016/07/az-online-vilagban-fontos-keziras-hogyan-hasznaljukaz-okosportalt/
} 
Valéria magyar-történelem szakos középiskolai tanárától megtudhatjuk, hogy „az online technika használata mellett kézzel is írniuk kell a diákoknak, az auditív és a vizuális érzékelés utáni jegyzetelés egy nagyon összetett folyamat, amely sokat segít a diákoknak a tanulásban, pl: a memorizáláshoz, rendszerezéshez is szükséges".

Az internetes közösség oktatási célú társas szerveződéseiről szinte mindent megtudhatunk Forgó Sándor „XXI. századi korszerü tanulási terek és formák” címü tanulmányából ${ }^{29}$. „Az elektronikus tanulási környezetben, napjainkban az online kommunikáció egyszerüsége lehetővé teszi, hogy a tanulók - a televíziós csatornákon elterjedt formákhoz hasonlóan, akár azon nyomban nyilvánosan, moderálatlan formában reagálhassanak a tanár vagy tanuló-társak által elmondottakra" - állapítja meg a tanulmány szerzője. Később ezt azzal egészíti ki, hogy „a magyarországi tanárképzésben még nem ment végbe az a paradigmaváltás, amelynek hatására a konnektivista tanulási módszereket és a web 2.0 eszközeit integrálnák a leendő tanárok módszertani kultúrájába, és a hallgatók már a képzésük során megismerkednének a módszer sajátosságaival.” Sajnos...

Azok számára, akik a tudásmegosztásról még több és föleg rendszerezett ismereteket akarnak szerezni, jó szívvel ajánlom az alábbi jegyzeteket, könyveket:

- Forgó Sándor: Tudáskonstrukció és -megosztás közösségi hálózatokon

- Papp-Danka Adrienn: Az online tanulási környezettel támogatott oktatási formák tanulás-módszertanának vizsgálata

- Forgó Sándor - Komló Csaba: Blended learning, tudásszervezés, hálózatalapú tudásmegosztás

- Pankász Balázs: Online oktatási környezet és IKT tényezők összehasonlító vizsgálata a felsőoktatásban ( $\mathrm{PhD}$ értekezés)

A tudásmegosztás új módszerei természetesen a pedagógus-továbbképzésekben is érzékelhető változást indukáltak. Erről tudhatunk meg többet „Az új típusú pedagógus-továbbképzések kínálata" címü prezentációból . Hogy melyek az új típusú továbbképzések főbb jellegzetességei? Î́me, a kulcsszavak:

- intézménybe kihelyezett,

- folyamatba ágyazott,

\footnotetext{
${ }^{29}$ http://rmpsz.ro/uploaded/tiny/files/magiszter/2010/tel/06.pdf
} 
- blended,

- moduláris,

- $\quad$ követő támogatást tartalmazó.

\section{A digitális eszközök iskolai alkalmazásának helyzete}

A számítástechnika-informatika tantárgy bevezetése óta kulcskérdés, hogy a nevelési-oktatási intézményekben rendelkezésre álló eszközök alkalmasak-e az éppen érvényes központi elvárások maradéktalan megvalósítására. A pedagógusok első reakciója legtöbbször az, hogy kevés a számítógép, nincs elegendő számítógépes tanterem, nem jut minden terembe interaktív tábla, projektor, nyomtató, a tanároknak nincs saját használatú laptopja, tabletje, gyenge a WiFi, a meglévő gépek elavultak stb.

A valóság ennél természetesen sokkal árnyaltabb, jóllehet messze vagyunk még az ideális állapotoktól.

2006-ban Kleininger Tamás „IKT-eszközök a földrajz oktatásában” címü cikkében $^{30}$ még azt írta, hogy „A világháló nálunk még nem vált a problémamegoldás, a széles körü információszerzés általános eszközévé. Különösen nem épült még be az internet alkalmazása az általános és középiskolás korosztály életébe, tanítási-tanulási tevékenységébe s a tanórán kívüli szabadidős ismeretszerző tevékenységekbe. Ennek sokféle oka van. Ezek közül az egyik s talán a legjelentősebb az, hogy a kapcsolódási lehetőséggel rendelkező iskolákban sincs jól szervezett rendszer a hálózat müködtetésére, kevés a szakértő rendszergazda. Sok iskolában a számítógépeket az informatika oktatásának rendelik alá, más szakos tanár nem is igen tud órát tartani a számítógépes termekben. Csak elvétve találkozni azzal, hogy a szaktanterem hátsó részén néhány számítógép segítségével a tanórán, csoportmunkában tudnak dolgozni a diákok.” Majd így folytatja: „A felmérések szerint jelenleg a tanulók internetezéssel töltött ideje átlagosan alig több napi fél óránál. Ez idő alatt még a Sulinetnél jobb egyetemi hálózaton sem lehet komolyabb keresőprogramokkal kutatni."

Körösné Mikis Márta „Az informatika helyzete és fejlesztési feladatai” címü, 2009 júniusában kelt tanulmányában ${ }^{31}$ mindenki számára egyértelmüen fogalmaz: „Az informatika tantárgy oktatásának kulcskérdése a taneszközök. Informatikát korszerü információtechnikai eszközök és segédanyagok nélkül ugyanis

\footnotetext{
${ }^{30} \mathrm{http}: / /$ epa.oszk.hu/00000/00035/00100/2006-02-in-Kleininger-Ikt.html

${ }^{31}$ https://www.ofi.hu/tudastar/tantargyak-helyzete/informatika-helyzete
} 
lehetetlen oktatni. Nélkülözhetetlenek a számítógépek, perifériáik, a kezeléstalkalmazást segítő szoftverek, az oktatási célú információs adatbázisok, a jól felszerelt iskolai könyvtár, az internetkapcsolat. Mindezek olyan mennyiségben, hogy minden tanuló hozzáférjen az információs és kommunikációs technika (IKT) nyújtotta lehetőségekhez. A tantárgy tantervi céljai, a tanulói tevékenységek csak ilyen környezetben valósíthatók meg. Míg a 'hagyományos' tantárgyak szemléltetéséhez (a fogyóeszközökkel dolgozó tantárgyak, iskolai laborok igényeit most figyelmen kívül hagyva) elegendő egyszeri beruházás, és bizonyos taneszközök akár több évtizedesek is lehetnek, addig - az igen gyors technikai fejlődésnek köszönhetően - az informatika eszközrendszere két-három éven belül elavul, cserélődik, amortizációja erkölcsi-mentális értelemben is jelentős."

Mgr. Námesztovszki Zsolt szabadkai pedagógus szintén 2009-ben az informatikai eszközök közül a digitális táblák jelentőség hangsúlyozta; „Interaktív tábla az oktatásban” címü jegyzetében ${ }^{32}$ a következőt olvashatjuk: „A pedagógus a hagyományos oktatási rendszerben előadói, szónoki képességeivel, gondolataival, tekintélyével és megjelenésével alapozta meg hitelességét. Manapság ezt ki kell egészíteni a pedagógus vizuális hitelességével is, amelyet a kivetített tananyag, a digitális táblán bemutatott tananyag, az elkészített távoktatási anyag, valamint ezek bemutatásának a hatékonysága alapoz meg."

Békési Attila, a Debreceni Egyetem egykori informatika szakos hallgatója 2010ben írt, „Az IKT eszközök az oktatásban” című szakdolgozatában ${ }^{33}$ egy átlagos kisvárosi általános iskola példáján mutatja be, „milyen mértékben terjedt el az információs és kommunikációs technológiák használata a szükséges oktatási megújulás tekintetében”, illetve „a pedagógusok mennyire érzik (...), hogy ezen eszközök és technológiák alkalmazása esetén a mindennapi munka és az oktatás hatékonysága jelentős mértékben megváltozik." Rávilágít azokra a problémákra is, amelyek akkoriban szinte valamennyi közoktatási intézményre jellemzőek voltak: „Pedagógus kollégáim és a megkérdezett diákok is jelezték, hogy szerintük több interaktív táblára és önálló, megfelelően felszerelt számítógépes laborra és osztályteremre lenne szükség ahhoz, hogy az IKT alkalmazása, használata kellő méretben terjedjen. (...) További nehézséget okoz sokszor az interneten történő információknak az elérése, letöltése, mivel a meglévő számítógéppark méretéhez és kiterjedéséhez képest alul lett tervezve a sávszélesség. A felső évfolyamon tanulók igényelnék a tanulói laptopok használatát is, mely segítséget nyújtana számukra a természetismereti tantárgyak

\footnotetext{
${ }^{32}$ http://blog.namesztovszkizsolt.com/wp-content/uploads/2009/10/regdigitalistabla.pdf

${ }^{33} \mathrm{https}$ ://dea.lib.unideb.hu/dea/bitstream/handle/2437/105068/Szakdolgozat_Bekesi_Atti la titkositott.pdf;jsessionid=4F77151B72BC73C91AD4F478F61FCB02?sequence=1
} 
megértéséhez. (...) A meglévő számítógépek informatikai szaktantermekben találhatók, és elsősorban az informatikaoktatást szolgálják..."

Az osztalyfonok.hu weboldalon 2015. március 17-én közzétett, „Az új nemzedék - digitális tanárjelöltek" címü cikkében ${ }^{34}$ a Digitális Nemzedék Konferencia egyik szekciójában előadó tanár szakos egyetemi hallgatók, illetve egy pedagógia szakos egyetemi oktató kutatásait mutatja be röviden. Figyelemre méltó a cikk bevezetőjének néhány mondata: „Az információs és kommunikációs technológiák jelentősen megváltoztatták életünket. A technológiai fejlesztések miatt sokak munkavégzésének, szórakozásának módja, mikéntje alakult át, de az új eszközök, programok minden bizonnyal a kommunikációra és a kapcsolattartásra gyakorolták legnagyobb hatásukat. Éppen ezért ma már nem az a kérdés, hogy belépünk-e a digitális világba, hanem az, hogy milyen mértékben van ez hatással életünkre. (...) Természetesen az iskolára, azt ott folyó munkára is befolyással vannak ezek a folyamatok, de ennek mértékére több tényező gyakorol hatás pl. az eszközellátottság, az érintettek attitüdje stb. Sokan emlegetnek generációs különbségeket a tanárok és tanulók között, pedig a fiatalok sem a „digitális eszközhasználat génjeivel" születnek. Az viszont igaz, hogy a korábbitól jelentősen eltérö, erősen digitalizált környezetben nőttek fel, mely a problémamegoldástól kezdve az informálódásig, kommunikációs szokásokig mindenre rányomja bélyegét."

A „Korszerü-e a digitális tudásunk” címü, 2015 októberében megjelent tanulmány egy érdekes ellentmondásra világít rá. A digitális kompetencia kérdései Magyarországon alcímet viselő írás szerzője szerint furcsa, hogy miközben „ma már a felnőttek és a tanulók nagy többsége hozzáfér az internethez, a digitális technika eszközei is szinte észrevétlenül életünk nélkülözhetetlen részévé váltak, tudnunk kell őket alkalmazni a munkahelyen, az iskolában, és persze otthon is, Magyarországon mégis kiemelkedően magas a digitális analfabéták száma, számukat kb. 3,3 millióra becsülik. A közvélekedéssel ellentétben a fiatal generáció nagy része sem használja készségszinten a digitális eszközöket, a látszólag folyamatos eszközhasználatuk gyakran kimerül az egyszerü szórakozásban.” A PISA-felméréseken utolsók vagyunk Európában „olyan kompetenciaterületeken, amelyek nélkül az OECD felmérései alapján a 21 . században nem lehet versenyképes egy munkavállaló sem”. Ha valaki azt gondolná, hogy az iskolák digitális eszközökkel való ellátottságának a hiányosságai okolhatók a fentiekért, az téved. A szerző szerint nem az elöregedett gépek a hibásak. „A romló színvonalú géppark és csökkenő ráfordítások viszont nem jelentik azt, hogy a magyar tanulók ne jutnának hozzá az alapvető IKTeszközökhöz. Hozzájutnak és használják is őket, sőt a környező országokhoz

\footnotetext{
${ }^{34}$ http://www.osztalyfonok.hu/cikk.php?id=1502
} 
képest több időt töltenek velük. Az iskolán kívüli internetezés idejét tekintve a régióban a tanulók 50-60\%-a két óránál is többet tölt az internettel. Az iskolában a magyar és szlovák diákok többet interneteznek, mint a cseh, lengyel vagy német diákok. Ugyanakkor nálunk, ahogy a matematika esetében, úgy a digitális szövegértés terén sem köszön vissza a befektetett idő a teljesítményben. (...) Az oktatási szakemberek lassan tíz éve figyelmeztetnek arra, hogy amikor már szinte teljes a számítógéphez való hozzáférés, akkor nem az IKT-eszköz (pl. a számítógép vagy az okostelefon) megléte vagy a használatára fordított idő hossza, hanem az aktivitás jellege az, amely leginkább összefüggést mutat a különbözö területen mért tanulói teljesítményekkel. A felmérések szerint a magyar diákok elsődleges IKT-s célja a szórakozás és kommunikáció az interneten, és jóval kevésbé jellemzőek rájuk a tanulást vagy az ismeretek bővítését célzó gyakorlatok. Vagyis az iskolának ösztönöznie kellene tanulóit az IKT kritikus, tudatos, hatékony használatára is."

S hogy milyen az informatikai eszközök és az infokommunikációs technológiák helyzete az iskolákban? Erre vonatkozóan ESSIE elnevezéssel még 2011 őszén végeztek felméréseket 27 európai országban, közöttük Magyarországon is. Az „IKT felmérés az európai iskolákban - A magyar eredményeken van mit javítani” című cikkből megtudhatjuk, hogy „a kutatás középpontjában az információs és kommunikációs technológiák oktatási intézményekben való alkalmazása állt. A több mint 190 ezer kérdőív válaszainak feldolgozására támaszkodó, az eredményeket összefoglaló tanulmány írója és koordinátora dr. Hunya Márta, az Oktatáskutató és Fejlesztő Intézet munkatársa volt. A kutatást az Európai Iskolahálózat és egy belga egyetem (University of Liège) végezte." A kutatás legfontosabb tanulságai közül álljon itt néhány:

- „A 9 évesek negyede, a 16 évesek fele jár digitálisan jól felszerelt iskolába (szélessávú internet, honlap, e-mail cím a tanulóknak és tanároknak, belső hálózat, virtuális tanulási környezet).

- A középiskolások (12 év felettiek) 20\%-a soha vagy majdnem soha nem használ számítógépet a tanítási órán.

- Jelentős különbség tapasztalható az országok között. A skandináv és az északi országok felszereltsége a legjobb (Svédország, Finnország, Dánia), míg leginkább Lengyelországban, Romániában, Olaszországban, Görögországban, Magyarországon és Szlovákiában hiányoznak a megfelelö eszközök.

- A korszerü eszközök hiánya nem jár az eszközök használata iránti érdektelenséggel. Néhány olyan ország is jó eredményt mutat a használat 
terén, ahol az infrastruktúra gyenge, pl. Bulgária, Szlovákia, Ciprus és Magyarország.

- A laptopok, tabletek, netbookok sok iskolában átvették az asztali számítógépek helyét.

- A legtöbb tanár úgy gondolja, hogy radikális oktatáspolitikai váltásra van szükség ezen a téren.

- A tanárok általában pozitívan állnak a tanulási célú eszközhasználathoz, de az alap- és középfokú képzésben dolgozó tanárok többsége „nem mozog magabiztosan" a digitális világban. Mivel a magabiztosság a digitális kompetenciafejlesztés kulcsa, a képzett és magabiztos tanárok fontosabbak, mint az, hogy a legmodernebb eszközök álljanak rendelkezésre.

- Az informatikai témájú tanár-továbbképzés általában nem kötelező, a tanárok jellemzően szabadidejükben, egyénileg szerzik meg a szükséges kompetenciákat.

- A tanárok gyakrabban használnak számítógépet a felkészülés során, mint az órákon."

A magyar helyzetről is találunk néhány érdekes adatot:

- Az iskolai számítógép-hozzáférés, azaz az egy gépre jutó tanulók aránya Magyarországon viszonylag jó, bár minden évfolyamon alatta marad kissé az európai átlagnak.

- Interaktív táblák tekintetében az európai élmezőnyben van Magyarország.

- Az európai intézmények 70\%-ában van teljes vagy részmunkaidős ún. IKT-koordinátor. Többségük (kb. 75\%) nem csak technikai, hanem pedagógiai segítséget is nyújt. $\mathrm{E}$ tekintetben minden korcsoportban Magyarország a sereghajó..."

Az Oktatáskutató és Fejlesztő Intézet a TÁMOP 3.1.1. projekt keretében, európai támogatással egy komplex mérőeszközt dolgozott ki az informatikai eszközök iskolafejlesztő célú használatának mérésére. A mérőeszközt eLEMÉR névre keresztelték. A kutatásfejlesztés részleteiről a moderniskola.hu weboldalon „Elemérés - IKT eszközök helyzete az iskolákban” címmel megjelent cikkben ${ }^{35}$,

\footnotetext{
${ }^{35}$ http://moderniskola.hu/2015/05/elemeres-ikt-eszkozok-helyzete-az-iskolakban/
} 
illetve az annak forrásául szolgáló „ELEMÉRÉS 2011-2015” című tanulmányban ${ }^{36}$ olvashatunk. Az első mérési eredményekről a „Gyorsjelentés az informatikai eszközök iskolafejlesztő célú alkalmazásának országos helyzetéről 2011. február 28án, eLEMÉR napján" című összefoglalóban ${ }^{37}$ tudósítanak a szerzők: Hunya Márta, Körösné Mikis Márta, Tartsayné Németh Nóra és Tibor Éva.

Az eLEMÉR mérőeszköz igen jó kritikát kapott Kárpáti Andrea professzorasszonytól, amint arról magunk is meggyőződhetünk, ha elolvassuk a szerző „Az eLEMÉR mérőeszköz kritikai elemzése” című írását ${ }^{38}$. Íme néhány mondat a tanulmány összegző értékeléséből: „Az eLEMÉR mint termék, tökéletesen megfelel a pályázatban elöírt feltételeknek, sőt, jelentős mértékben túlteljesíti azokat. Nemcsak diagnosztizál, de terápiát is javasol, nemcsak informál, de orientál is. Mintaszerü a portál szerkezete, amely együtt, egy helyen teszi elérhetővé a vizsgálati eszközt, használatának ismertetését, a vele kapcsolatos képzéseket, tájékoztatókat és a felmérés első eredményeit. A felmérés valamennyi produktumát segítő, pozitív attitüd hatja át. Nem ellenőriz, hanem segít, nem minősít, hanem felmutatja az értéket és jelzi a hiányt."

\section{Kismintás pedagógus interjú}

Annak érdekében, hogy közvetlen tapasztalatokra is szert tegyek a pedagógusoknak a digitális biztonsághoz, a digitális adatvédelemhez kapcsolódó ismereteiről, illetve a digitális eszközök iskolai alkalmazásáról alkotott nézeteiről, személyes beszélgetést szerveztem egy helyi középiskola néhány tanárával. Az alábbiakban néhány mondatban összefoglalom a tapasztaltakat.

- A digitális oktatási stratégiáról valamennyien hallottak már, de arra a provokatív kérdésre, hogy szerintük ez már egy elfogadott dokumentum vagy csak tervezet, senki sem mert határozott választ adni. (Megjegyzem, az iskola igazgatójával történt elözetes beszélgetésből kiderült, hogy az iskola vezetése „hivatalból” hallott már Magyarország Digitális Oktatási Stratégiájáról, hiszen a helyi pedagógiai programjukba be is kellett építeni annak néhány elemét...)

- Valamennyien használnak számítógépet (notebookot, tabletet, iPadet, okostelefont), illetve internetet a tanórákra való felkészüléshez, illetve az iskolai adminisztrációhoz.

\footnotetext{
${ }^{36} \mathrm{http}: / /$ ofi.hu/publikacio/elemeres-2011-2015

${ }^{37} \mathrm{http}$ ://ofi.hu/sites/default/files/ofipast/2011/04/Gyorsjelentes 2011.pdf

38 http://folyoiratok.ofi.hu/sites/default/files/article_attachments/upsz 2012 4-6_6 14.pdf
} 
- A tanítási órákra viszont csak egy részük „viszi be” az IKT-t; érdekes módon, a matematika szakosok általában maradnak a hagyományos (fali tábla, kréta) megoldásnál. Szívesen veszik igénybe az informatika nyújtotta lehetőségeket a bölcsészek, a nyelvszakosok, illetve a természettudományi tárgyakat tanítók. Az iskola házirendje tiltja a tanulóknak a telefonok, okoseszközök tanórán való használatát, de a pedagógusok egy része időnként ,feloldja” ezt a tilalmat a saját óráján. Többen említették az okosportált ${ }^{39}$ (hivatalos nevén Nemzeti Köznevelési Portál), illetve az azon belül is megtalálható, de külön is elérhető Zanza $\mathrm{Tv}^{40}$,adásait”. A tankönyvek egy részében is találunk olyan feladatokat, amelyek az interneten való kutatásra sarkallják a diákokat. A házi feladatok között is akad olyan, amihez használniuk kell a digitális eszközöket.

- A számonkérés során nem használnak számítógépet a pedagógusok.

- Az internetes elektronikus naplók közül a mozaNaplót rendszeresítették az intézményben.

- Az iskolában két számítógépes labor müködik, amelyeket szinte kizárólag az informatika oktatására, illetve ECDL vizsgáztatásra használnak. Az osztálytermek közül négyben található interaktív tábla, viszont mindegyikben megoldható a kivetítés hordozható számítógép, illetve projektor segítségével. Az iskola nem biztosít a pedagógusok saját használatára laptopokat, viszont egy pályázati lehetőséget kihasználva a tantestületből többen jutottak mobileszközökhöz.

- A tanulók jelentős része rendelkezik (saját tulajdonban lévő) okostelefonnal, de ezek használatát - ahogy fentebb is említettem - a házirend erősen korlátozza.

- Van az iskolában elérhető WiFi, de a kollégák megítélése szerint nem elegendő a sávszélesség, illetve a jel erőssége is változó az iskola különböző pontjain. Az is gondot okoz időnként, hogy az informatikai rendszergazda bizonyos korlátozásokat vezetett be a hálózat használatára vonatkozóan; több olyan weboldalt is letiltott - a pedagógusokkal való előzetes egyeztetés nélkül -, amelyekre időnként a tanórán is szükség lenne.

\footnotetext{
${ }^{39} \mathrm{https}$ ://portal.nkp.hu/

${ }^{40}$ https://zanza.tv/
} 

oktatási alkalmazásáról való gondolkodásának feltáró jellegü vizsgálata

- Védett online közösségek nincsenek; a tanárok közül néhányan emailben, illetve a Facebookon tartják a kapcsolatot a jelenlegi és a volt diákjaikkal. A digitális biztonság, illetve a digitális adatvédelem kérdésében a pedagógusok meglehetősen tájékozatlanok.

- Abban valamennyien egyetértettek a jelenlévők, hogy a digitális eszközöket, illetve az általuk kínált lehetőségeket nem lehet kihagyni a tanítási-tanulási folyamatokból. A digitális átállás elkerülhetetlen, de a megvalósításnak az M-DOS-ban tervezett ütemezését illetően nem túlságosan derülátók. Többségük szerint nem az eszközellátottság hiányosságainak felszámolásához, hanem a pedagógusok szemléletváltásához kell még nagyon sok időnek eltelnie... 


\section{Ajánlott mérések, illetve mérôeszközök a megcélzott fókuszterületen}

Az Oktatáskutató és Fejlesztő Intézet a TÁMOP 3.1.1. projekt keretében, európai támogatással egy komplex mérőeszközt dolgozott ki az informatikai eszközök iskolafejlesztő célú használatának mérésére. A mérőeszközt eLEMÉR névre keresztelték. A megcélzott fókuszterületeken elvégzendő mérésekhez az eLEMÉR iskolai önértékelő rendszer online tanári ${ }^{41}$ és tanulói kérdőívét ${ }^{42}$ ajánlom.

\begin{tabular}{|l|c|c|c|c|c|}
\hline $\begin{array}{l}\text { Kutatás/felmérés } \\
\text { neve }\end{array}$ & Hatókör & Célközönség & $\begin{array}{c}\text { Megjelenés } \\
\text { éve }\end{array}$ & Típusa & $\begin{array}{c}\text { Elérhető, } \\
\text { nyilvános-e a } \\
\text { méróeszköz }\end{array}$ \\
\hline $\begin{array}{l}\text { eLEMÉR iskolai } \\
\text { önértékelő } \\
\text { rendszer tanári } \\
\text { kérdőív }\end{array}$ & hazai & tanár & 2011 & $\begin{array}{c}\text { online } \\
\text { kérdőív }\end{array}$ & igen \\
\hline $\begin{array}{l}\text { eLEMÉR iskolai } \\
\text { onnértékelö } \\
\text { rendszer tanulói } \\
\text { kérdőív }\end{array}$ & hazai & tanuló & 2011 & $\begin{array}{c}\text { online } \\
\text { kérdöív }\end{array}$ & igen \\
\hline
\end{tabular}

A kérdőívekhez használati útmutató ${ }^{43}$ is tartozik.

\footnotetext{
${ }^{41} \mathrm{http} / / /$ docplayer.hu/14644723-Elemer-iskolai-onertekelo-rendszer-tanari-kerdoiv.html

${ }^{42} \mathrm{http} / / /$ docplayer.hu/23367542-Elemer-iskolai-onertekelo-rendszer-tanuloikerdoiv.html

${ }^{43}$ http://digitalistemahet.hu/uploads/faa2d9b784986bf1a2c3c4cf10d411dc.pdf
} 

oktatási alkalmazásáról való gondolkodásának feltáró jellegü vizsgálata

\section{Felhasznált irodalom}

\subsection{Magyarország Digitális Oktatási Stratégiája}

http://www.kormany.hu/download/0/cc/d0000/MDO.pdf

\subsection{Digitális biztonság, adatvédelem}

https://www.slideshare.net/ollejanos/digitlis-felelssg-digitlis-etikett-digitlisbiztonsg

https://www.digitaliscsalad.hu/biztonsag/digitalis-biztonsag-szuloket-el-kell$\underline{\text { erni/ }}$

https://www.digitaliscsalad.hu/biztonsag/ne-dobd-oda-gyereked-pedofiloknak/

https://www.digitaliscsalad.hu/biztonsag/ezert-ne-posztolj-kepet-gyerekedrol/

https://www.digitaliscsalad.hu/elmeny/videojatekok-rosszak-nem-gondolnankmennyi-mindenben-segithetnek-gyereknek/

https://www.digitaliscsalad.hu/elmeny/tizeves-gyerekem-megkapta-elsookostelefonjat/

https://hirlevel.egov.hu/2017/08/05/a-digitalis-jolet-program-es-az-ivszkozosen-kezdemenyezi-egy-it-biztonsagi-szakmai-forum-lerehozasat/

https://naih.hu/files/CELEX 32016R0679 HU TXT.pdf

https://twobirdsideas.hu/2016/05/04/2018-majus-25-etol-kell-alkalmazni-az-euuj-adatvedelmi-rendeletet/

https://mno.hu/fogyasztovedelem/adatvedelem-es-internet-tanitani-kene-agyerekeknek-1269935

http://profit7.hu/magazin-1/digitalis-iskolakezdes-lenyeg-a-biztonsag

http://slideplayer.hu/slide/2946935/

https://summers.hu/ecdl/s6/jegyzetek/it.pdf

http://www.kifu.gov.hu/kifu/sites/default/files/IT brosura v7.pdf 
https://www.betterinternetforkids.eu/documents/2067076/2162084/Checklist_Po sitiveContent_provider_producer_HU.pdf/c9418535-8f6e-4d63-ab45$\underline{5 \mathrm{e} 232515 \mathrm{~b} 251}$

https://www.nytimes.com/2015/02/09/technology/uncovering-security-flaws-indigital-education-products-for-schoolchildren.html

https://edtechmagazine.com/k12/article/2016/10/4-tips-help-schools-privacyand-security-compliance

http://hechingerreport.org/keeping-student-data-safe-era-digital-learning

http://www.dataprotectionschools.ie/en/

https://www.stonegroup.co.uk/data-protection-act-affects-schools/

\subsection{A tudásmegosztás offline és online jellemzői}

http://www.iskolakultura.hu/iol/iol_2009_42-51.pdf

http://www.osztalyfonok.hu/cikk.php?id=677

http://epa.oszk.hu/00000/00011/00169/pdf/EPA00011_Iskolakultura_201210_011-042.pdf

$\underline{\text { http://www.osztalyfonok.hu/cikk.php?id=1240 }}$

http://www.kre.hu/ebook/dmdocuments/oktatasi_segedanyag/chap_16.html

http://recity.hu/tudasmegosztas-kivel-mikor-hogyan/

http://media20.blog.hu/2014/11/22/hogyan hasznalja a mediat a z-generacio

http://moderniskola.hu/2016/07/az-online-vilagban-fontos-keziras-hogyanhasznaljuk-az-okosportalt/

http://rmpsz.ro/uploaded/tiny/files/magiszter/2010/tel/06.pdf

http://mek.oszk.hu/14100/14178/pdf/14178.pdf

http://www.eltereader.hu/media/2015/01/Papp_Danka_A_Online_tanulasi_REA DER.pdf 
http://p2014-25.palyazat.ektf.hu/public/uploads/6-blended-learningtudasszervezes-halozatalapu-tudasmegosztas-forgo-sandor-komlo-csabaisbn_565d55661de45.pdf

http://pea.lib.pte.hu/bitstream/handle/pea/15706/pankasz-balazs-phd-2016.pdf

https://www.educatio.hu/pub_bin/download/tamop315/roadshow_2014majus/ta mop315roadshow_kepzesek.pdf

\subsection{A digitális eszközök iskolai alkalmazásának helyzete}

http://epa.oszk.hu/00000/00035/00100/2006-02-in-Kleininger-Ikt.html

https://www.ofi.hu/tudastar/tantargyak-helyzete/informatika-helyzete

http://blog.namesztovszkizsolt.com/wpcontent/uploads/2009/10/regdigitalistabla.pdf

https://dea.lib.unideb.hu/dea/bitstream/handle/2437/105068/Szakdolgozat_Bekes i_Attila_titkositott.pdf;jsessionid=4F77151B72BC73C91AD4F478F61FCB0 2 ? sequence $=1$

http://www.osztalyfonok.hu/cikk.php?id=1502

http://tizperciskola.blog.hu/2015/10/27/korszeru-e digitalis tudasunk

http://observatory.org.hu/ikt-felmeres-az-europai-iskolakban-a-magyareredmenyeken-van-mit-javitani/

http://moderniskola.hu/2015/05/elemeres-ikt-eszkozok-helyzete-az-iskolakban/ $\underline{\text { http://ofi.hu/publikacio/elemeres-2011-2015 }}$

http://ofi.hu/sites/default/files/ofipast/2011/04/Gyorsjelentes_2011.pdf

http://folyoiratok.ofi.hu/sites/default/files/article attachments/upsz 2012 46_14.pdf

\subsection{Ajánlott mérések, illetve mérőeszközök a megcélzott fókuszterületen}

http://docplayer.hu/14644723-Elemer-iskolai-onertekelo-rendszer-tanarikerdoiv.html 
http://docplayer.hu/23367542-Elemer-iskolai-onertekelo-rendszer-tanuloi$\underline{\text { kerdoiv.html }}$

http://digitalistemahet.hu/uploads/faa2d9b784986bf1a2c3c4cf10d411dc.pdf 